\title{
Teacher Candidates' Attitudes to Using Oral History in History Education
}

\author{
Ebru Demircioğlu \\ Correspondence: Ebru Demircioğlu, Karadeniz Teknik Üniversitesi, Fatih Faculty of Education, Trabzon, Turkey
}

Received: February 25, 2016 Accepted: March 16, 2016 Online Published: April 11, 2016

doi:10.11114/jets.v4i6.1405

URL: http://dx.doi.org/10.11114/jets.v4i6.1405

\begin{abstract}
The aim of this research is to determine the views of history teacher candidates towards an oral history project carried out in the Special Teaching Method Course of the history pedagogy program of the Fatih Faculty of Education (FFE) at Karadeniz Technical University in Turkey. An open-ended questionnaire and semi-structured interview were the main data collection tools of this study based on a qualitative approach. 86 history teacher candidates in the pedagogy program filled out the questionnaire and 20 of them participated in interviews. In light of the gathered data it seems that teacher candidates gained basic knowledge and skills in how to conduct oral history in history education. Besides this, they also recognized that oral history is one of the important approaches to supporting active learning in history lessons, and that this approach could make history lessons interesting and enjoyable.
\end{abstract}

Keywords: history education, oral history, history teacher education

\section{Introduction}

History education has been given great attention by the Turkish state since the establishment of the Turkish republic. It has been seen as the cement for constructing the values of the nation state and the state has been involved in the history curriculum and textbook preparation process during the republican period (Demircioğlu, 2015). Although it has been given so much attention, history education faces some problems in practice in the classroom. For example, some students see history lessons as boring and uninteresting because of the abstractness of the teaching and the emphasis on memorization (Demircioğlu, 2011; Demircioğlu, 2001). Yet, although history is an abstract subject, it can be brought up to date by using different methods and approaches. One way of bringing history up to date is to make a connection between schools and the people in the local area (Lyons, 2007). Oral history can be used to do this in history lessons. In other words, history teachers can use oral history to bring history into the present, and this can also help teachers to make history lessons more interesting, enjoyable and understandable (Demicioğlu, 2005).

Oral history is a method of collecting historical information: by interviewing an individual about his or her memories of past events (Veccia, 2004). Huerta and Flemmer (2000, p. 111) make a similar statement, that “... oral history is a collection of an individual's thoughts and recollections of about his or her past based on audio or visually recorded interviews conducted by a researcher." Oral history research received the attention of historians after World War II because researchers could easily access tape-recorders, and there was an interest in history from the bottom up, i.e. the social history of non-elites (Sommer and Quinlan, 2009). Besides this, oral history helps historians to illuminate previously poorly documented areas of history, such as the history of women, families and ordinary people (Brooks, Aris and Perry, 1993). For this reason, oral history has become one of the main data collection tools of some historians since World War II.

Oral history is also one of the teaching tools in history lessons (Demircioğlu, 2005; Busby, 2011; VanSledright, 2004, cited in Lattimer and Kelly, 2013; Crocco, 1998 cited in Hansen, 2014). Busby (2011) states that "Oral history is one instructional approach that provides a learning experience for students in which they can learn history in a personal and meaningful way." Besides this, oral history is a versatile classroom tool for expanding students' understanding of events and of periods in history (Crocco, 1998 cited in Hansen, 2014). Furthermore, activities that explore oral history give opportunities to students to actively participate in the construction of an understanding of history, rather than view the official historical narrative (VanSledright, 2004, p. 232 cited in Lattimer and Kelly, 2013).

Using oral history in history lessons was looked at by history teachers in the last quarter of the $20^{\text {th }}$ century because in this period, active history teaching based on learning by doing, examining evidence, questioning, problem solving and developing empathy was accepted as the best way of teaching, especially in developed countries such as the UK, the USA and Canada (Phillips, 2002). One way of engaging in active learning through doing in history lessons is by 
engaging in oral history projects, which is an interesting and stimulating teaching activity (Demircioğlu, 2005). History teachers teaching in primary and secondary schools can use oral history as a teaching approach in their classrooms to develop the skills and knowledge of their students (Brooks, Aris and Perry, 1993; Demircioğlu, 2005). Some of these benefits can be listed as follows:

- Develops research skills (Demircioğlu, 2005).

- Develops skills of working together (Demircioğlu, 2005).

- Helps those students who have limited reading skills (Brooks, Aris and Perry, 1993).

- Helps students carry out interviews (Brooks, Aris and Perry, 1993).

- Develops questionnaire skills (Brooks, Aris and Perry, 1993).

- Helps students to build up a meaningful chronological framework (Brooks, Aris and Perry, 1993, Demircioğlu, 2009).

- Helps students to learn by doing (Brooks, Aris and Perry, 1993).

- Develops personal skills, such as learning to listen (Brooks, Aris and Perry, 1993).

- Develops historical enquiry skills (Garg, 2007).

- Develops organization and presentation skills (Garg, 2007).

- Provides students with an opportunity to experience history first-hand (Garg, 2007).

- Increases student understanding of a specific historical event (Garg, 2007).

- Allows students to act as real historians (Busby, 2011).

- Extends their understanding beyond the limits of the textbook (Busby, 2011).

- Helps students learn that oral history is subjective and dependent on the interpretation of the recorder (Busby, 2011).

- Enriches students' understanding (Crocco, 2010).

- Synthesizes students' interview notes and helps them write narratives (Hansen, 2014).

The above-listed skills are very important for active learning in history classrooms. Furthermore, these skills are also important for the people of those countries which have a liberal democracy if they are to bring up well-educated citizens in the $21^{\text {st }}$ century.

Teachers are recommended to use oral history in their teaching activities in different countries (Brooks, Aris and Perry, 1993; Nichol and Dean, 1997; Edwards, 2006; Garg, 2007; Kitson, Husbands and Steward, 2011; Fischer, Costache and Makriyianni, 2011; Demircioğlu, 2005). In Turkey, there was a curriculum reform in the last decade, since when history teachers have been advised to use active teaching approaches in their teaching activities, one of which is oral history (MEB, 2007; MEB, 2008). In other words, history teachers are expected to know how to implement oral history activities in their classrooms in Turkey. For this reason, using oral history in history education should be a part of the history teacher education program.

Teaching how to implement oral history is an important topic in universities of developed countries, and there are courses dealing with it. Besides this, research has been done into using oral history in teacher education and schools. For example, Busby (2011) carried out research with social studies teacher candidates to promote historical inquiry through an oral history project. Busby concluded that conducting an oral history project is vital for pre-service teachers if they are able to implement this strategy in their own classroom (Busby, 2011). Besides this, there are several studies that look at the implementation of oral history in primary and secondary schools, and the results of this research state that oral history supports active learning (Penyak and Duray, 1999; Crocco, 2010; Lattimer and Kelly, 2013; Hansen, 2014).

In Turkey, it seems that there is no academic study regarding oral history that has been carried out with history teacher candidates based on action research. However, there have been other studies looking at oral history. Akbaba and Kilcan (2014) researched the attitudes of social studies teacher candidates towards oral history. In the light of their research, it seems that those social studies teacher candidates who are interested in historical novels, stories and memory have positive attitudes to oral history. There are also theoretical studies that mention the importance of using oral history in teacher education and education in Turkey. For example, Uygun (2011) claims that oral history is an effective teaching method for learning about the past. Besides this, Demircioğlu (2005) has explained how to conduct oral history projects in history lessons and education. 


\subsection{The Aim of the Research}

The main aim of this research was to ascertain history Turkish teacher candidates' views about an oral history project conducted by history teacher candidates. Considering the main aim of this research, the following questions were developed in the light of the research questions determined by Demircioğlu (2008).

1-What are the views of history teacher candidates about the oral history project they conducted themselves?

2-What kinds of skills do history teacher candidates gain by conducting oral history projects?

\section{Procedures}

History teacher candidates on the pedagogy program of the FFE in Trabzon have to take a Special Teaching Method Course, which runs for 15 weeks, with four hours per week based on theory and teaching activities, teaching them how to teach history. Teacher candidates are expected to develop knowledge and skills, such as the aim of history teaching, teaching methods, techniques, concepts and values. Besides this, they are also given education assessments, are taught planning, and shown how to use oral and local sources and museums in history education. The Special Teaching Method Course of the FFE requires teacher candidates to carry out some teaching projects, one of which is using oral history in history education.

In this action research, first of all teacher candidates were educated in oral history and how to conduct an oral history project in history education. Second, they were asked to carry out oral history projects as group study, and they set up into working groups of four students each. Third, they were asked to identify an oral history topic, and then every group had to prepare a main research problem and sub-problem, and then each group had to carry out a literature research and prepare interview questions about their oral history project. Fourth, the history teacher candidates were required to share and discuss their research problems, the results of their literature review, and their interview questions with their friends in the classroom. Fifth, the teacher candidates found people who were suitable for their project and conducted interviews with them. Furthermore, they wrote up the results of their project. Besides this, all groups were asked to present results of their oral history project in front of their classmates and researcher. Finally, the researcher evaluated each project.

History teacher candidates carried out oral history projects with retired history teachers, teachers of other subjects and ordinary people who are silversmiths, jewelers and woods craftsmen, the latter of whom were masters in regional, hand-embroidered gold and silver and regional hand-crafters. The oral history project focused on five main topics, which were problems of history education, the value of the teacher in society, changes in the production of hand-made jewelry, and changes in regional hand-craft production in the province of Trabzon. As the results of the oral history project were examined, valuable data regarding the above topics were derived. The main results of the oral history projects can be listed as follows:

1-History education faced problems from 1980 to 2000 in Turkish society, such as students' inability to memorize, high levels of state involvement, and the poor quality of history textbooks, because of the traditional approach adopted in this field. Besides this, there has been a loss of political interest in national history by the state because of the EU membership process.

2-The value and reputation of teachers decreased in Turkish society from 1980 to 2000 because of the poor quality of qualified teachers and the inadequate teacher education system.

3-Interest in the production of regional, hand-made gold and silver jewelry decreased among people of the province of Trabzon from 1990 to 2010 because of new techniques in the technological production of jewelry.

4-Interest in the production of regional hand-crafts in the province of Trabzon decreased from 1990 to 2010 because of the new methods of technological production.

5-The earnings of regional hand-crafters decreased from 1990 to 2010 because of these new technological production methods.

The above results are the result of the data that teacher candidates gathered from different people in the region of Trabzon, so that they could implement what they learned about oral history into their education faculties.

\section{Methodology}

Research was a small-scale action research and based on a qualitative approach to gathering deep data from history teacher candidates. First of all, a literature review about oral history and how to use oral history in education was carried out by the researcher. Second, data collection tools-a semi-structured interview and an open-ended questionnaire-were developed in the light of the research questions. The main aim behind using a semi-structured interview and an open-ended questionnaire was to gather high quality deep information concerning the research problem (Verma and Mallick, 1999). 


\subsection{Participants Characteristics}

The research was conducted in the history pedagogy program of the FFE at Karadeniz Technical University in Trabzon, which is the largest city in the East Black Sea region of Turkey. The FFE is a well-established education faculty in Turkey. The participants of the research (48 male-38 female) were the final year students of history department of Art Faculty of Karadeniz Technical University. They were from different parts of Turkey and came to Trabzon for their university education. The participants in this study had to obtain a degree in pedagogy to take the national exam (KPSS) in order to become a history teacher in Turkish high schools. For this reason, they enrolled in the history pedagogy program of the FFE in the final year of their education.

\subsection{Data Collection Tools and Implementation}

The first data collection instrument was an open-ended questionnaire comprising 5 questions, some of which were developed based on the questions of Sözbilir (2007) and Demircioğlu (2008) (see Appendix 1). The same questions were used in the semi-structured interview and the questionnaire to elicit the views of teacher candidates about their oral history project. Open-ended questions were used in this research to obtain deep and meaningful data. A pilot study regarding the semi-structured interview and the open-ended questionnaire was carried out with 10 teacher candidates evaluating the questions from the data collection tool. Some minor rectifications to both the questionnaire and the semi-structured interviews were made after the pilot study.

The open-ended questionnaire used in this research was distributed to 90 history teacher candidates in April 2015 in the FFE at Karadeniz Technical University. 86 questionnaires were returned to the researcher. 20 of the teacher candidates who responded to the questionnaire were chosen by a random sampling method for the semi-structured interviews, a method supported by Verma and Mallick (1999 cited in Demircioğlu, 2008). Each teacher candidate was interviewed separately by the same researcher, who took notes and used a tape-recorder during the interviews. Interviews were carried out in the education faculty.

\subsection{Analysis of the Gathered Data and its Validity}

The descriptive analysis approach was used in this research, and in order to analyze the responses of the open-ended questionnaire and semi-structured interviews the following approach was used in this study. First of all, data gathered from questionnaires and interviews were read. Second, codes and categories were created by researcher. Third, a double analysis of data by two researchers was made to test the reliability of data.

\section{Results and Discussion}

The results of this study show that the oral history project had a significant impact on history teacher candidates, and that the great majority found the project valuable. Besides this, they commented that they gained new knowledge and experience about how oral history can be used in history lessons. However, teacher candidates found this project too time consuming. The following results emerged from the data.

In this research, first of all, history teacher candidates on the pedagogy program were asked what the most valuable and least valuable aspects of the oral history project were. In the light of the data, it seems that the great majority of responders found the project valuable. Besides this, their responses indicate that the oral history project provided different experience and skills to each of the teacher candidates. Table 1 indicates that the great majority of responders $(95,3 \%)$ thought that the most valuable aspect of the oral history project was learning how to carry out an oral history project in history lessons. Furthermore, $89,5 \%$ of teacher candidates believed that they learned how to collect personal information from people, some of which sorts of information are not in textbooks or official history. On the other hand, $86 \%$ of teacher candidates thought that the least valuable aspect of the oral history project was that it took up too much time. 
Table 1. What were the most valuable and least valuable aspects of the oral history project?

\begin{tabular}{lll}
\hline Perceptions & $f$ & $\mathbf{9}$ \\
\hline Learned how to carry out an oral history project in history lessons & $\mathbf{8 2}$ & $\mathbf{9 5 , 3}$ \\
Learned how to collect personal information from people, some of which is not in the & $\mathbf{7 7}$ & $\mathbf{8 9 , 5}$ \\
textbooks or official history & $\mathbf{7 4}$ & $\mathbf{8 6}$ \\
Oral history activities took too much time & $\mathbf{7 1}$ & $\mathbf{8 2 , 5}$ \\
Learned how to make history lessons interesting, and benefit from oral history & $\mathbf{6 8}$ & $\mathbf{7 9}$ \\
Learned how to formulate a research question for oral history & $\mathbf{6 4}$ & $\mathbf{7 4 , 4}$ \\
Recognized that people have different points of view about past events & $\mathbf{6 1}$ & $\mathbf{7 0 , 9}$ \\
Learned how to prepare an interview
\end{tabular}

The results of the interviews about the above questions are in line with the results of the questionnaires. The great majority of the teachers (17) who gave an interview stated that they found the oral history project an important activity for developing some crucial skills. For example, teacher candidate 6 commented that, "This project is very important for us and we gained knowledge and skills regarding how to conduct an oral history project with high school students in history education. We recognized that using oral history makes history lessons interesting and enjoyable. Besides this, we learned how to make a literature review, how to formulate a research question, how to prepare and analyze an interview. In addition to this, how to write a research project." History teacher candidate 3 made a similar statement, saying that, "The oral history project was a great project to make history lessons enjoyable. As we are taught, some students find history lessons boring because of talk and chalk. Oral history can be used in history lessons to overcome this problem. Besides this, we learned how to plan and finish an oral history project because of this project." On the other hand, all of the teacher candidates found that the time-consuming nature of the oral project was its least valuable aspect. The results of the questionnaire and interview are in line with each other, and it seems that history teacher candidates learned how to conduct an oral history project in history education.

The second question regarding the data collection tools of this research asked whether or not the teacher candidates thought that this kind of assignment should be prepared by teacher candidates. If their answer was yes, they were required to give their reasons. Table 2 indicates that the majority of respondents $(86 \%)$ believed that teacher candidates should conduct oral history projects in history education. Besides this, $82,5 \%$ of teacher candidates stated that they should recognise that the best way of learning about the past is to do so by way of an oral history project.

Table 2. Do you think that this kind of project should be prepared by teacher candidates? If you answer 'yes' to this question, could you please explain your reasons?

\begin{tabular}{lll}
\hline Perceptions & $f$ & $\mathbf{\%}$ \\
\hline Teacher candidates should conduct an oral history project in history education & $\mathbf{7 4}$ & $\mathbf{8 6}$ \\
$\begin{array}{l}\text { Teacher candidates should recognize that the best way of learning about the past is to } \\
\text { do it through an oral history project }\end{array}$ & $\mathbf{7 1}$ & $\mathbf{8 2 , 5}$ \\
$\begin{array}{l}\text { Teacher candidates should learn how to put theory into practice } \\
\text { Teacher candidates should recognize that oral history builds a bridge between the } \\
\text { classroom and society }\end{array}$ & $\mathbf{6 1}$ & $\mathbf{7 0 , 9}$ \\
$\begin{array}{l}\text { Teacher candidates should develop skills of working together by way of oral history } \\
\text { projects }\end{array}$ & $\mathbf{5 7}$ & $\mathbf{6 6 , 2}$
\end{tabular}

The interview findings from the above question indicate that majority of teacher candidates believed that they should prepare these kinds of projects. For example, teacher candidate 14 stated that, "History teacher candidates should prepare these kinds of projects in teacher education institutions. We learned how to make a history lesson interesting and beneficial by [using an] oral history project. Furthermore, we also learned how theory could be put into practice." Besides this, teacher candidate 2 noted that, "Projects and assignments are important in the teacher education process. We learned how to put theory into practice by using oral history projects, and gained important knowledge and skills. For this reason, history teacher candidates should be involved in these kinds of projects." In the light of the questionnaire and interview results, it is clear that the great majority of history teacher candidates thought that teacher candidates should prepare this kind of project.

Another question put to teacher candidates was how the oral history project influenced their views on the use of oral history in teaching practice. In the light of the data it seems that the majority of responders $(87,2 \%)$ recognized that oral history is one of the best ways of making history lessons interesting. Besides this, $78 \%$ of teacher candidates thought that oral history is one of the best ways of teaching history actively. 
Table 3. How has carrying out the oral history project influenced your views on the use of oral history in teaching practice?

\begin{tabular}{lll}
\hline Perceptions & $f$ & $\mathbf{\%}$ \\
\hline $\begin{array}{l}\text { Recognized that oral history is one of the best ways of making history lessons } \\
\text { interesting }\end{array}$ & $\mathbf{7 5}$ & $\mathbf{8 7 , 2}$ \\
Recognized that oral history is one of the best ways of teaching history actively & $\mathbf{6 8}$ & $\mathbf{7 9}$ \\
Recognized that oral history is one of the best ways of developing students' research & $\mathbf{6 1}$ & $\mathbf{7 0 , 9}$
\end{tabular}
skills

Data based on the results of interviews produced are in line with the questionnaires' results. History teacher candidate 19 commented that, "The oral history project had a positive impact on us. We recognized that oral history could be one of the best ways of making history lessons interesting in the eyes of students in history classrooms. Besides this, history lessons can be taught actively using oral history activities." Teacher candidate 9 made a similar statement: "This project positively affected our views about using oral history in history lessons. We recognized that oral history could make history lessons beneficial and interesting in the eyes of students. Besides this, we recognized that student can develop thinking and research skills by oral history activities in history lessons." The results both of the interviews and questionnaire show that teacher candidates thought that using oral history is important in teaching practice and is one of the important ways of teaching history in an active way.

Teacher candidates were also asked how oral history projects affect history education in the classrooms. The great majority of history teacher candidates $(93 \%)$ thought that oral history supports active learning in teaching history topics in history classrooms. Besides this, $89,5 \%$ of teacher candidates thought that oral history makes history lessons enjoyable. Furthermore, $79 \%$ of teacher candidates believed that oral history helps students to recognize that there could be different viewpoints on one single event in the past in history lessons.

Table 4. How does oral history project affect history education in the classroom?

\begin{tabular}{lll}
\hline Perceptions & $f$ & $\mathbf{\%}$ \\
\hline Oral history supports active learning regarding history topics in history classrooms & $\mathbf{8 0}$ & $\mathbf{9 3}$ \\
Oral history makes history lessons enjoyable & $\mathbf{7 7}$ & $\mathbf{8 9 , 5}$ \\
Oral history helps students to recognize that there could be different viewpoints on & $\mathbf{7 1}$ & $\mathbf{8 2 , 5}$ \\
one single event in the past & $\mathbf{6 8}$ & $\mathbf{7 9}$ \\
Oral history develops the research skills of students in history classrooms & $\mathbf{6 3}$ & $\mathbf{7 3 , 2}$ \\
Oral history develops learning about local culture & $\mathbf{6 1}$ & $\mathbf{7 0 , 9}$ \\
Oral history helps students to understand the nature of history & $\mathbf{5 7}$ & $\mathbf{6 6 , 2}$ \\
Oral history socializes students outside the school
\end{tabular}

The results of the interviews concerning the above question are in line with the results of the questionnaire. All teacher candidates stated that using oral history lessons has a positive effect on history education. For example, teacher candidate 4 said that, "Oral history is one of the most important approaches that supports active learning in history education. Today in Turkey many teachers use lectures in history lessons, which makes history lessons unbeneficial and uninteresting. For this reason, history teachers should use active teaching approaches, one of which is bringing oral history into history education." In addition to this, teacher candidate 11 explained that, "Oral history affects history education in a positive way. Students can gain some crucial skills, such as research, effective questioning and thinking in history lessons." The above explanations indicate that history teacher candidates think that oral history has a positive effect on history education in history classrooms.

The final question of the questionnaire and interview was how teacher candidates could use the skills and knowledge they gained when they became history teachers. Table 5 indicates that the great majority of responders thought that they would be able to use the skills and knowledge that they gained through oral history projects. $93 \%$ of the teacher candidates thought that they could implement an effective oral history project when they became history teachers. Besides this, $84,8 \%$ of teacher candidates thought they could teach how to carry out oral history to their students in history lessons.

Table 5. How might you use the knowledge and skills gained from the oral history project when you become a teacher?

\begin{tabular}{lll}
\hline Perceptions & $f$ & $\mathbf{6}$ \\
\hline I can carry effective oral history projects in history lessons & $\mathbf{8 0}$ & $\mathbf{9 3}$ \\
I can teach how to carry out oral history projects to my students in history lessons, to & $\mathbf{7 3}$ & $\mathbf{8 4 , 8}$ \\
develop their skills & $\mathbf{6 8}$ & $\mathbf{7 9}$ \\
I can use oral history to teach local customs & $\mathbf{4 7}$ & $\mathbf{5 4 , 6}$ \\
I can teach my colleagues how to carry out an oral history project
\end{tabular}

The responses to the questionnaire about the above question are in line with the results of the interviews. For instance, teacher candidate 1 stated that, "We gained important skills and knowledge regarding how to implement effective oral history projects, and I can conduct similar projects with my students in my history lessons." Teacher candidate 10 made 
a similar statement, that, "This project was one of the most beneficial projects which I carried out in the pedagogy program. I can carry out similar projects with my students to make history lessons interesting. Besides this, I can also teach my colleagues in my school how to conduct oral history projects when I become a history teacher in a high school." The results, based on responses of students, indicate that teacher candidates thought that they could use oral history in their teaching when they become teachers.

\section{Conclusion and Recommendations}

This project aimed to illustrate the views of history teacher candidates about their oral history project, carried out at their Special Teaching Method Course pedagogy program at Karadeniz Technical University in Turkey. The results of the research indicate that the great majority of teacher candidates found the oral history project valuable, and learned how to conduct oral history in history education in their project. In the light of the gathered data, the main results of this study can be summarized as follows. First of all, teacher candidates learned the importance of oral history in history education and how to conduct an oral history project in history lessons. Second, teacher candidates stated that history teacher candidates should learn and carry out activities involving oral history in history education, because the best way of learning about the past is by way of an oral history project. Third, teacher candidates claimed that oral history is one of the best way of making history lessons interesting and developing students' thinking skills. Fourth, it emerged that oral history supports active learning in history lessons, and students were able to recognize that there could be different viewpoints on one single event in the past. Finally, teacher candidates commented that they could carry out an effective oral history project, based on the skills and knowledge they gained, when they became history teachers.

Some outcomes of this study were in line with suggestions of some researchers. First, using oral history as a teacher is supported by Brooks, Aris and Perry (1993), Nichol and Dean (1979), Edwards (2006), Garg (2007), Kitson, Husbands and Steward (2011), Fischer, Costache, and Makriyianni (2011) and Demircioğlu (2005). In this study, the fact that teacher candidates recognized that oral history supports active learning is in line with the results of Penyak and Duray (1999), Crocco (2010), Lattimer and Kelly (2013) and Hansen (2014). Second, teacher candidates' claim that oral history is one of the best ways of making history lessons interesting and for developing students' thinking skills is in line with the results of Brooks, Aris and Perry (1993) and Demircioğlu (2005). Finally, it emerged that oral history supports active learning in history lessons; and the idea that students could recognize that there could be different viewpoints on one single event in the past is in line with the results of Demircioğlu, 2005 and Busby (2011).

The following recommendations can be made in the light of the results of this study:

- History teacher education programs should add education in oral history.

- History teacher education programs should train teachers how to conduct oral history in history education.

- History teacher candidates should be required to carry out projects for implementing oral history in history education.

This research made the following contributions to the related literature. First, conducting a research project about how to use oral history in the teacher preparation process has a positive impact on developing the skills and knowledge of history teacher candidates regarding the use of oral history. Second, this research is an example of how teacher candidates can be involved in oral history projects in the history teacher education process. Third, this research provides empirical data which will help researchers and history teacher educators who are interested in oral history and the use of oral history in education.

\section{References}

Akbaba, B., \& Kilcan, B. (2014). Prospective social studies teachers' attitudes towards oral history studies, Elementary Education Online, 13(3), 746-758.

Brooks, R., Aris, M., \& Perry, I. (1993). The Effective teaching of history, London, Longman.

Busby, R. S. (2011). Learning through Doing: Preserviceteacher training in historical inquiry through oral history projects, The Oral History Review, 1-10. http://dx.doi.org/10.1093/ohr/ohr048

Crocco, M. S. (1998). Putting the Actors Back on Stage: Oral History in the Secondary School Classroom, Social Studies, 89(1), 19-24. http://dx.doi.org/10.1080/00377999809599817

Demircioğlu, İ. H. (2001). Does the teaching of history in Turkey need reform? International Journal of Historical Learning, Teaching and Research, 2(1). http://centres.exeter.ac.uk/historyresource/journal3/turkey.pdf

Demircioğlu, İ. H. (2005). Tarih öğretiminde öğenci merkezli yaklaşimlar, Ankara: Anı Yayıncılık.

Demircioğlu, İ. H. (2008). Learning how to conduct educational research: a Turkish perspective, Australian Journal of Teacher Education, 33(1), 1-17. http://dx.doi.org/10.14221/ajte.2008v33n1.1 
Demircioğlu, İ. H. (2009). Tarih öğretmenlerinin tarihsel düşünme becerilerine yönelik görüşleri, Milli Eğitim, 184, 228-239.

Demircioğlu, İ. H. (2011). Educating secondary school history teachers in Turkey and England, Berlin, VDM Verlag.

Demircioğlu, İ. H. (2015). History teacher education and history education in Turkey, In Elisabeth Erdmann, Wolfgang Hasberg, (Eds.), History teacher education: Global interrelations (pp. 123-141), WochenSchauVerlag, Berlin.

Edwards, C. (2006). Putting life into history: How people can use oral history to become critical historians, Teaching History, 123, 21-25.

Fischer, C., Costache, S., \& Makriyianni, C. (2011). Introducing Oral History, Nicosia: K\&L Lithofit LTD.

Garg, B. (2007). Teaching of history, New Delhi: Rajat Publication.

Hansen, B. G. (2014). Oral history project: Lithuanian students study the past to gain skills for the future, International Journal of Education, 6(3), 216-228. http://dx.doi.org/10.5296/ije.v6i3.6229

Huerta, G. C., \& Flemmer, L. A. (2000). Using-student generated oral history research in the secondary classroom, Social Studies, May/June, 110-115. http://dx.doi.org/10.1080/00377990009602452

Kitson, A., Husbands, C., \& Steward, S. (2011). Teaching and learning history, 11-18, Berkshire: Open University Press.

Lattimer, H., \& Kelly, M. (2013). Engaging Kenyan secondary students in an oral history project: education as emancipation, International Journal of Educational Development, 33(99), 476-486. http://dx.doi.org/10.1016/j.ijedudev.2012.05.007

Lyons, J. F. (2007). Integrating the family and the community into the history classroom: an oral history project in joliet, illinois, History Teacher, 40(4), 481-491.

MEB (2007). Tarihdersiögretimprogrami (9. sinif), Ankara: MilliEğitimBasımevi.

MEB (2008). OrtaöğretimçağdaşTürkvedünyatarihidersiöğretimprogrami, Ankara: MilliEğitimBasımevi.

Miles, M. B., \& Huberman, A. M. (1994). Qualitative data analysis, Thousand Oaks, Sage Publications.

Nichol, J., \& Dean, J. (1997). History 7-11: developing primary teaching skills, London: Routledge.

Phillips, R. (2002). Reflective teaching of history, 11-18, London: Continuum.

Sommer, B. W., \& Quinlan, M. K. (2009). The oral history manual, New York: Altamira Press.

Sözbilir, M. (2007). First steps in educational research: the views of chemistry and biology student teachers. European Journal of Teacher Education, 30(1), 41-61. http://dx.doi.org/10.1080/02619760601120072

Uygun, S. (2011). Türkiye'desözlütariharaştirmalariveöğretmeneğitimindesözlütarihyöntemininkullanilmasi, AkademikAraştırmalarDergisi, 50, 95-112.

Veccia, S. H. (2004). Teaching with primary sources, Chicago: American Library Association.

Verma, G. K., \& Mallick, K. (1999) Researching Education. London: Falmer Press.

\section{Appendix 1: The Questions used in the Questionnaire and Interview}

1: What were the most valuable and least valuable aspects of the oral history project?

2: Do you think that this kind of project should be prepared by teacher candidates? If you answer 'yes' to this question, could you please explain your reasons?

3: How has carrying out the oral history project influenced your views on the use of oral history in teaching practice?

4: How does the oral history project affect history education in the classrooms?

5: How might you use the knowledge and skills gained by the oral history project when you become a teacher?

\section{$(\mathrm{Cc}) \mathrm{BY}$}

This work is licensed under a Creative Commons Attribution 3.0 License. 